\title{
Implementation of the remote indigenous community empowerment program on the sustainability of the local food crops in West Papua, Indonesia
}

\author{
LAZARUS INDOW ${ }^{1}$, RUDI A. MATURBONGS ${ }^{1,2}$, SARASWATI PRABAWARDANI ${ }^{1,3, \bullet}$, HENDRI ${ }^{1,2}$, \\ GRAHAM LYONS \\ ${ }^{1}$ Environmental Science Graduate Program, Universitas Papua. J1. Gunung Salju, Amban, Manokwari 98314, West Papua, Indonesia \\ ${ }^{2}$ Faculty of Forestry, Universitas Papua. Jl. Gunung Salju, Amban, Manokwari 98314, West Papua, Indonesia \\ ${ }^{3}$ Faculty of Agriculture, Universitas Papua. Jl. Gunung Salju, Manokwari 98314, West Papua, Indonesia. Tel./fax.: +62-986-211430, `email: s.prabawardani@ unipa.ac.id \\ ${ }^{4}$ School of Agriculture, Food and Wine, University of Adelaide. Waite Campus, PMB 1, Glen Osmond, SA 5064, Australia
}

Manuscript received: 7 October 2021. Revision accepted: 8 November 2021.

\begin{abstract}
Indow L, Maturbongs RA, Prabawardani S, Hendri, Lyons G. 2021. Implementation of the remote indigenous community empowerment program on the sustainability of the local food crops in West Papua, Indonesia. Biodiversitas 22: 5247-5254. An ethnobotanical study of local food crops in the areas receiving the program of remote indigenous community empowerment (RIC) in the three ecosystem areas of Domberai, West Papua was conducted to assess the effect of the program on specific local food crops. This study used a descriptive method with qualitative and quantitative data components. Surveys and field observations were carried out at predetermined village locations, using a purposive sampling interview method with community representatives, tribal chiefs, and leaders in each indigenous community. Field data were analyzed quantitatively to find the value of the benefit index (BI) on food crops. Results of the study showed the highest BI values of carbohydrate-rich crops were banana (Musa sp.) which accounted for 98\%, sweet potato (Ipomoea batatas) 98\%, followed by taro (Colocasia esculenta) 94\%, and cassava (Manihot esculenta) 90\%. Vegetable crops with the highest BI values were gedi leaves (Abelmoschus manihot) 98\%, papaya leaves (Carica papaya) 86\%, followed by sweet potato leaves (Ipomoea batata) 56\%, cassava leaves (Manihot esculenta) 56\%, gnetum leaves (Gnetum gnemon) 55\%, and pumpkin leaves (Cucurbita) $52 \%$. The highest BI values in fruit crops were rambutan (Nephelium lappaceum) $72 \%$, mango (Mangifera indica) $70 \%$, and durian (Durio zibethinus) 59\%. The shift from local food crops to rice has been observed in the villages of Sakumi and Yamboi which are relatively accessible for transportation, while the people of Watitindoi Village, which is located on a small island and is isolated, have been mostly relied on local food crops.
\end{abstract}

Keywords: Ethnobotany, local food crops, remote indigenous community, West Papua

\section{INTRODUCTION}

Remote Indigenous Communities (RIC) are one of the community groups that are often neglected in development, and their socio-economic life conditions are backward when compared to other community groups and often placed as second-class citizens (Suradi et al. 2019). RIC is a local community group that is left behind, has less access to social services, both in the field of economic, social, and political and less doing contact with the surrounding community, lives more below the poverty line, and underdevelopment (Hatu 2020). The livelihoods of this community depend on the local natural resources, using very simple technology, a subsistence economy, and limited access to basic social services. Remote indigenous communities must be wisely and sustainably maintained (Iswandi et al. 2015). To overcome problems experienced by indigenous people, the Ministry of Social Affairs of the Indonesian Republic, issued Regulation No. 39 of 2012 concerning the Implementation of Social Welfare, as well as Presidential Regulation of the Indonesian Republic No. 186 of 2014, launched the Remote Indigenous Community Empowerment Program. The program covers population administration, religious life, health, learning, food security, job opportunities, land access, advocacy and legal assistance, social services, and the environment. The direction of the RIC empowerment program is to increase the ability and independence of RIC residents without losing the cultural color in the form of local wisdom and traditional knowledge in achieving life welfare or improving people's quality of life (Hatu 2020).

West Papua Province, which covers an area of $102,946.15 \mathrm{~km}^{2}$, has diverse physiography ranging from islands, coasts, lowland valleys to mountains with an altitude of $2940 \mathrm{~m}$ above sea level, inhabited by about 71 ethnic indigenous tribes (Statistical Central Bureau of West Papua 2020). Each ethnic group interacts with the natural environment in which they are located, thus forming their cultural system according to their environment. West Papua has cultural diversity spread over two customary areas, namely Domberai and Bomberai. The elements of universal culture differ based on their ecological zones.

Population data for Remote Indigenous Communities in West Papua in 2018 was 12,539 families spread over 12 regencies and one city in 437 locations or villages. Villages that receive the RIC program are located in various areas 
with different types of ecosystems, namely highlands, lowlands, and islands or small islands. From the total population, 3,851 people have been empowered and 8,260 people have not been empowered; hence more than half of the RIC population in West Papua Province has not yet been empowered. The RIC empowerment program in West Papua has not yet been evaluated from the community perspective, for example, in the socio-cultural aspects of RIC residents related to their traditional wisdom and knowledge, including the ethnobotany of local food crops.

Ethnobotany makes a major contribution in the effort to explore and record the traditional wisdom and knowledge of the local community as the nation's cultural treasures. Helida et al. (2016) revealed that ethnobotanical knowledge could be an indicator of the success of resource management, including plant resources. Various traditional concepts contain wisdom that can overcome the nation's problems both from the aspect of basic human needs or in environmental management efforts (Simbiak 2016). Ethnobotany is the knowledge of various types of plants related to their traditional use and management by various ethnic groups. Several ethnobotanical analyses in the use of plants are widely known by the public, but their scientific documentation is still limited (Batoro 2015). The existing data shows an increasing relevance of traditional ethnobotanical knowledge and is considered as an invaluable, underutilized, and under-documented knowledge (Leret et al. 2016). However, ethnobotany studies are needed to study the concept of local knowledge of indigenous peoples about plants which are the result of cultural development. Local knowledge has great cultural significance and refers to the use of many wild or domesticated resources and the management of natural habitats and agroecosystems, as well as to some other important rural activities and practices (Carvalho and Moreira 2011; Cassino et al. 2018).

Local Papuan food crops are consumed and locally produced in Papua for economic and or various consumption purposes. The question in this study is whether, with the presence of the RIC program, the community still maintains the ethnobotany of Papua's specific local food crop resources. Since the inclusion of the RIC empowerment program allows the development of cultural modernization flows, the use of local food plants can slowly be eroded by the introduction of food crops from outside. This study aims to examine the implementation effect of the RIC empowerment program on the ethnobotanical status of local food crops in the three villages with different ecosystems, i.e. Wondama Bay District, South Manokwari District, and Arfak Mountains District, in the Domberai customary area, West Papua.

\section{MATERIALS AND METHODS}

\section{Study area}

This study was conducted over five months, from February to June 2019, in three ecological zones of remote indigenous communities (RIC) in West Papua Province, Indonesia (Figure 1), which include: (i) Yamboi Village, Ransiki Sub-district, South Manokwari District, in the lowland ecological zone, occupied by the Hatam and Sough Tribes; (ii) Sakumi Village, Anggi Gida Subdistrict, Arfak Mountains District, highland ecological zone (foothill forest ecosystem, $400 \mathrm{~m}$ above sea level), occupied by Hatam and Sough Tribes; (iii) Watitindau Village, Rumberpon Sub-district, Teluk Wondama District, island zone, occupied by Wamesa and Soughbohon Tribes.
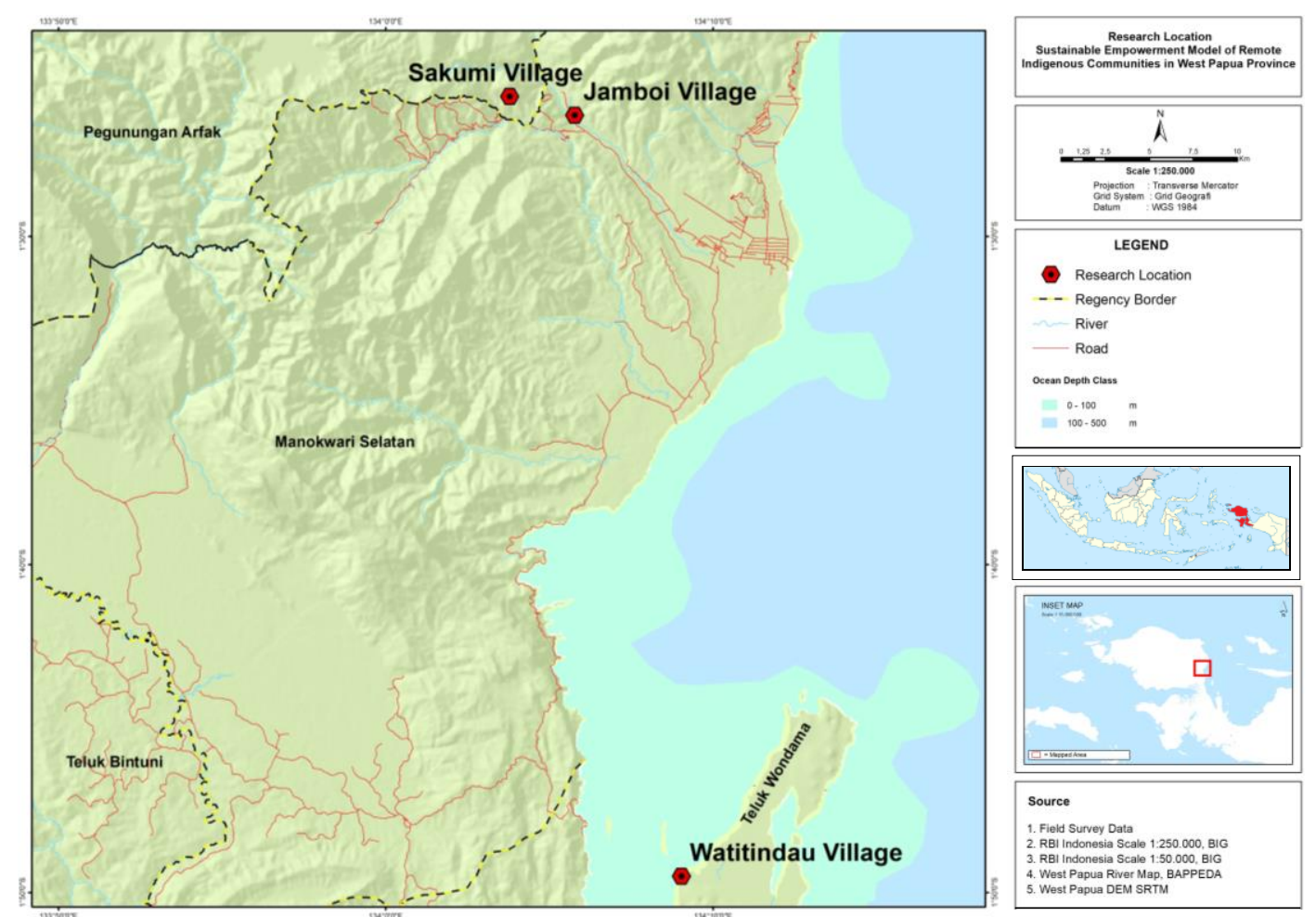

Figure 1. Map of the study area in Sakumi, Jamboi, and Watitindau villages of West Papua Province, Indonesia 


\section{Data collection}

This study used a descriptive method with qualitative and quantitative approaches. The research technique was in the form of surveys and field observations at predetermined village locations. Determination of the key informants was done by purposive sampling (deliberately) based on the following criteria: (i) Integrate with local RIC empowerment program activities; (ii) Actively involved in the local RIC empowerment program; (iii) Available; and (iv) Provide actual information. Informants consisted of representatives of local indigenous peoples, tribal chiefs, categorical leaders, or figures in each remote indigenous community.

The variables observed were components of the traditional RIC's wisdom and knowledge through an ethnobotanical approach on the species of plants used as staple food crops, vegetables, and fruit crops. Data were collected through observation, in-depth interviews, and document analysis. This indicated how the implementation of the Remote Indigenous Community Empowerment program affected the ethnobotanical aspects of food crops in selected villages.

\section{Data analysis}

Qualitative analysis in this study followed the interaction model of Miles and Huberman (1994). The analysis activity began with data collection in the field, data reduction, data presentation, and verification. While quantitative analysis employed the benefit index (BI), the index indicates that the more a plant is beneficial, the higher the BI value (Batoro 2015). The benefit index is calculated following the equation:

$$
\mathrm{BI}=\frac{\mathrm{Ji} \times 100 \%}{\mathrm{~N}}
$$

Where:

BI : benefit index

$\mathrm{Ji}$ : the number of occurrences of the use of a plant

$\mathrm{N}$ : the total number of occurrences of the use of a plant

The value of $0-33 \%$ is categorized as low $\mathrm{BI} ; 34-69 \%$ (medium $\mathrm{BI}$ ), and $>70 \%$ (high $\mathrm{BI}$ )

The data obtained from the survey results are presented in tabulated form, then analyzed descriptively with a quantitative approach.

\section{RESULTS AND DISCUSSION}

\section{The status of local food crops}

The results showed that the level of community satisfaction with local food in three RIC villages with different ecological types was as follows: $40 \%$ of the people of Sakumi Village highly preferred the local food crops, $50 \%$ preferred the local food crops and $10 \%$ moderately prefer the local food crops. On the other hand, $100 \%$ or all of the people of Yamboi and 30\% of the people of Watitindau Village highly preferred the local food crops. Whereas, $20 \%$ of people of Watitindau Village prefer the local food crops and 50\% moderately preferred the local food crops (Table 1). These results indicate that the dependence on local food crops is very high in the communities in the remote RIC locations, which are located on small islands with minimal transport access. However, with the inclusion of the RIC program and an increase in transportation accessibility, it encourages people to travel, especially to the central city. The culture and food patterns of various urban communities from various regions in Indonesia have influenced and shifted the culture or local food patterns of carbohydrate sources in remote indigenous communities. In Table 1 , it can be seen that the level of community satisfaction with local food crops varies from highly preferred or very favored, prefer or favored to moderately preferred or moderately liked. Meanwhile, all respondents highly preferred (much liked) or had a high level of satisfaction with local food crops in Yamboi Village. These results indicate that the local food crops are still favored by the people in the three villages receiving the RIC empowerment program, despite the fact that the eating frequency of the local food has been slowly declining as rice has now frequently been consumed. According to Aswani et al. (2018) in many countries, rural communities and indigenous peoples face extraordinary cultural, economic, and environmental changes, which can contribute to the decline of their local knowledge and resource base.

Table 1. Responses of the people of Sakumi, Yamboi, and Watitindau Villages, West Papua Province, Indonesia towards plant sources for food

\begin{tabular}{lcccc}
\hline Variable & \multicolumn{4}{c}{$\begin{array}{c}\text { Village } \\
\text { Sakumi Yamboi Watitindau BI } \\
\text { Percentage (\%) }\end{array}$} \\
\hline Level of satisfaction with local & & & & \\
food crops & & & 30 & \\
$\quad$ Highly preferred & 40 & 100 & 20 & \\
Prefer (like) & 50 & - & 50 & \\
$\quad$ Moderately preferred & 10 & - & & \\
Commonly consumed local & & & & \\
staple food & & & 100 & 98 \\
$\quad$ Banana & 95 & 100 & 95 & 98 \\
Sweet potato & 100 & 100 & 91 & 94 \\
Taro & 100 & 92 & 100 & 90 \\
Cassava & 95 & 75 & 5 & 31 \\
Taro (bete) & 63 & 25 & 23 & 19 \\
Corn & 26 & 8 & 27 & 9 \\
Sago & - & - & & \\
Source of food & & & \\
$\quad$ Garden & 100 & 100 & 100 & \\
$\quad$ Yard & 10 & 40 & 40 & \\
\hline Note: BI: benefit index value & & &
\end{tabular}



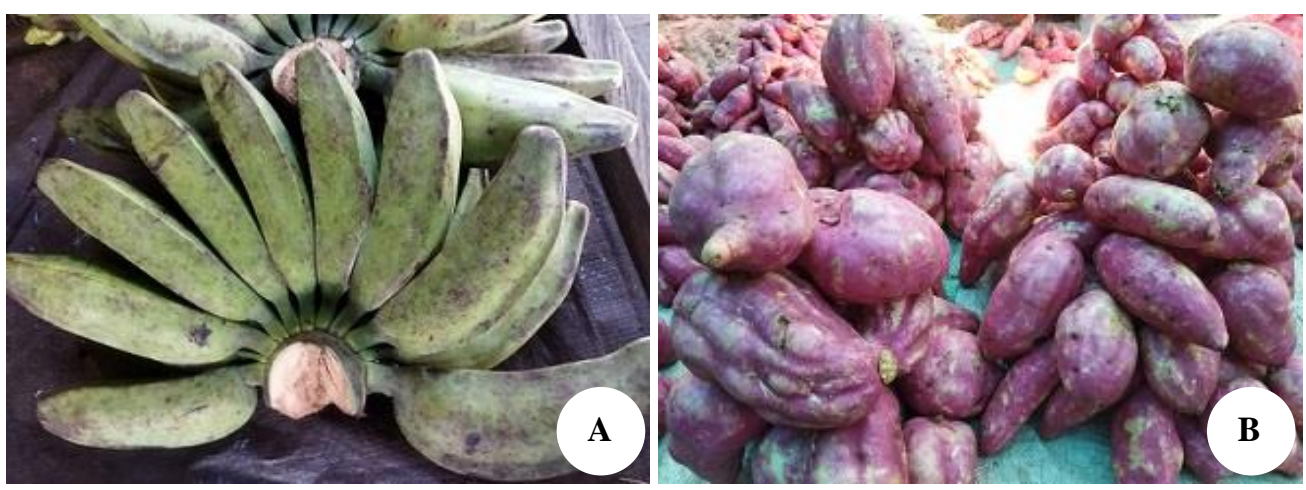

Figure 2. The highest benefit index of staple food crops: (A) banana and (B) sweet potato

The study area with relatively more adequate transportation access makes it easier for people to obtain food from outside, such as rice. The ease and interest of the community to switch and consume rice is supported by the government program in the form of Rice for the Poor (Raskin) which is the government's efforts to ensure food security for its people by providing subsidized rice at low and affordable prices. This program was formed to help poor families have good access to energy-rich food, i.e. rice, in terms of price and availability.

The Raskin program led people to start switching to rice consumption and lessening the local staple food crop cultivation activities, as shown by a decrease in land area and sweet potato production in the West Papua region (Statistical Central Bureau of West Papua 2020). Ramandey (2017) stated that the distribution of Raskin can affect the level of craftsmanship of the poor in working to meet their daily needs. Ironically, rice that should be produced to meet the demand of people in West Papua Province is still imported (Anggraeni 2020). The productivity of rice in West Papua is still below the national productivity with a limited planting area. As an illustration, in 2015 the productivity of rice in West Papua was 4 tons/ha, while the national productivity was 5 tons/ha (Statistical Central Bureau of West Papua 2016). Therefore, the production has not been able to meet the needs of the West Papua people. On the other hand, the trend of local food crop production of sweet potatoes tends to decrease (Statistical Central Bureau of West Papua 2020).

Sweet potato and taro were local staple food sources of carbohydrates, followed by bananas and cassava which are commonly consumed by the people of Sakumi Village. Whereas in Yamboi Village, the main local food items consumed were bananas and sweet potatoes, followed by taro and cassava. In addition to bananas, cassava, sweet potatoes, and taro, sago was a staple food consumed by the people of Watitindau Village with 27\% (Table 1). Watitindau has a limited sago area that grows naturally. The sago land in Watitindau Village is located in the coastal area of the small island and can be reached by four hours speedboat ride from the capital of Teluk Wondama District, West Papua. For the people of coastal areas in Papua, sago is one of the staple foods, but in general, they still depend on natural sago. According to Tjokrokusumo
(2018), the important value of sago palm as a staple food has not changed in some Indonesian areas including in Papua. Arwam et al. (2021) revealed that most Nebes Village community in West Papua depends on the natural sago forests. Likewise, people in other areas of Papua are also depending on the natural sago forests. It implies that the Papuan people are mostly unaccustomed to sago cultivation techniques. Thus efforts to cultivate and protect sago forests must be conducted to prevent erosion of food sources or sago germplasm. According to the local people, sago is also used as traditional medicine. Sago flour is soaked with water to heal sore throat and fever in children. They also said that before the use of zinc at this time, sago leaves in ancient times were used as roofs.

The results of the analysis of the benefits index of food crops from an average of three locations showed that banana and sweet potato had the highest benefit value, followed by taro and cassava. These plants are not only consumed on a household scale, but also as an economic source for the family. Bananas and sweet potatoes had the highest benefit index (Figure 2). Bananas are not only used as a source of carbohydrates but also used as fruit crops that contribute to the economy and other benefits. The banana blossom is used as a vegetable ingredient, while the soft part inside of the stem is used as animal feed. Banana leaves are not only used for various purposes but also as a medicine for wounds related to skin problems.

Sweet potatoes showed a high benefit index because apart from consuming sweet potatoes, they are also marketed as a source of household income. While the young leaves are eaten as vegetables and used as traditional medicine. Islam (2006) revealed that sweet potato leaves contain a high content of polyphenols, namely anthocyanins and phenolic acids, compared to commercial vegetables. Sweet potato leaves consist of at least 15 biologically active anthocyanins which have significant medicinal value for certain human diseases. Sweet potato leaf is a very versatile and delicious vegetable that has high nutritional value and is a valuable medicinal plant that has anti-cancer, antidiabetic, and anti-inflammatory substances (Mohanraj and Sivasankar 2014). Apart from utilizing the tubers, taro leaves are used as vegetables and medicine. Cassava tubers are cooked as a source of carbohydrates, and the leaves as vegetables. 


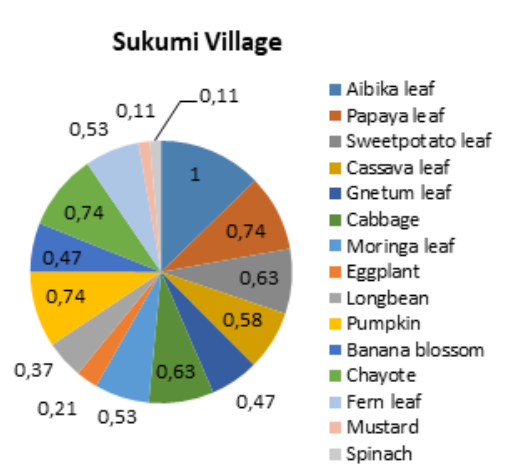

A

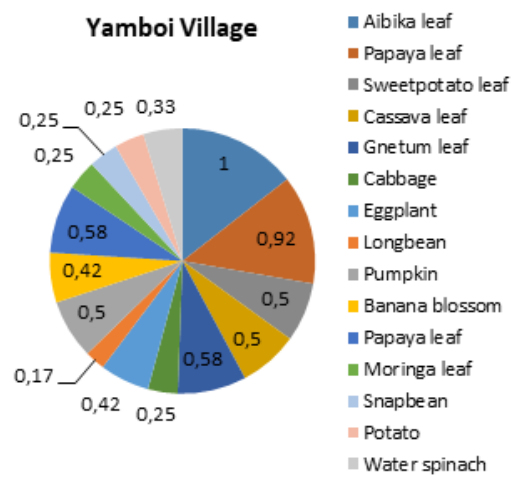

B

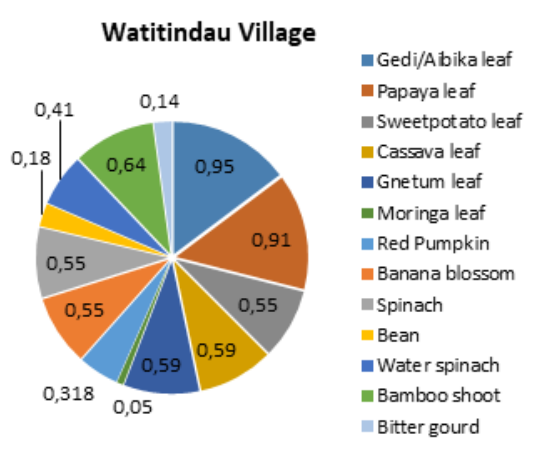

C

Figure 3. Types of vegetable crops that are commonly consumed by the people of West Papua Province, Indonesia: A. Sukumi, B. Yumboi, C. Watitindau villages

Table 2. Food status and rice consumption of the people of Sakumi, Yamboi and Watitindau villages, West Papua Province, Indonesia

\begin{tabular}{lccc}
\hline \multirow{2}{*}{ Variable } & \multicolumn{3}{c}{ \% (Percentage) } \\
& Sakumi & Yamboi & Watitindau \\
\hline Frequency of eating rice (before RIC & program) & \\
1-2 days/week & 84 & 100 & 95 \\
3-4 days/week & 11 & - & 5 \\
More than 4 days/week & 5 & - & - \\
Frequency of eating rice (after RIC program) & \\
1-2 days/week & 11 & 25 & 95 \\
3-4 days/week & 63 & 33 & 5 \\
More than 4 days/week & 26 & 42 & - \\
\hline
\end{tabular}

Communities in the three villages have extensive knowledge of local food management. Most of the food crops are harvested from the garden and a small part is cultivated in the yard (Table 1). These results indicate that local food crops have an important role for indigenous peoples to meet their daily food needs. Therefore, all local food crops should be preserved to maintain more production, security, and sustainability for future food needs (Bilali et al. 2018; Domingo et al. 2021).

Sago, bananas, and sweet potatoes are staple food crops of Papuan people that have a long history linked to their traditional livelihood. However, in the three villages studied, it has been recorded that rice has become popular. Before the RIC empowerment program entered remote areas in West Papua, most of the remote indigenous people consumed rice only 1-2 days/week (Table 2). However, after the RIC empowerment program entered the area, the frequency or number of days of rice consumption increased. Of the total population, $63 \%$ of the people in Sukumi Village consume rice in 3-4 days/week, 26\% more than 4 days/week, and $11 \%$ within 1-2 days/week. In Yamboi Village, $42 \%$ of the people consume rice more than 4 days/week, $33 \%$ in 34 days/week, and $25 \%$ in 1-2 days/week. On the other hand, $95 \%$ of Watitindau people consume rice within 1-2 days/week, and only $5 \%$ for more than 4 days.

This result showed that the people of Watitindau Village located on a small and remote island have limited access to rice. Therefore, people who are located in remote locations and are constrained by transportation access will depend on local food resources. According to Coelho et al. (2018) that the consumption of local food produced in a local environment with ecological-based technology is beneficial to the environment, economy, and society in general. The local farmers always purchase but do not cultivate rice, as ecologically the land areas are not suitable for rice cultivation, and culturally people have not used to intensive farming.

\section{Benefit index of vegetable crops}

The type of vegetable consumed by the people in the three RIC empowerment program villages was gedi in the local name (Aibika in Papua New Guinea). This leafy vegetable is eaten daily by the community and ranks first in the type of vegetables preferably consumed by the people of the Sukumi, Yamboi, and Watitindauw villages (Figure 3 ). The gedi plant is a functional plant for the Papuan people, considering its nutritional and traditional medicinal value. Therefore, this plant occupies every lawn, garden, and yard of the Papuans. The gedi plant has adapted and developed locally for a long time in Papua and is a plant that has social and cultural values that are so attached to the Papuan people. This plant is not only consumed to meet the needs of minerals and vitamins for the family but also as a source of income (Saraswati et al. 2016). Gedi vegetables are not only in demand by indigenous Papuans but this plant is also favored by immigrant communities from outside Papua, especially from Eastern Indonesia (Saraswati et al. 2016) and people of PNG and Pacific Island countries (Lyons et al. 2020). Part of gedi that is eaten as vegetables is the young leaves or shoots. Local people utilize gedi leaves for pregnant women to facilitate childbirth and to treat various diseases. It has been traditionally used for the treatment of inflammation, pain, urinary infection, and chronic bronchitis (Todarwal et al. 2011). Gedi is rich in bioactive components including flavones, polysaccharides, tannic acid, and long-chain hydrocarbons, particularly total flavones are the major active component (Chen et al. 2012). Gedi leaves contain high protein, vitamins (Vitamins $\mathrm{A}$ and $\mathrm{C}$, riboflavin, thiamin, niacin, lutein), and minerals (potassium, magnesium, calcium, manganese and iron, and zinc). Thus, gedi leaves hold an important role in counteracting micronutrient deficiencies (Lyons et al. 2015; Tuia et al. 2015; Saraswati et al. 2016). 


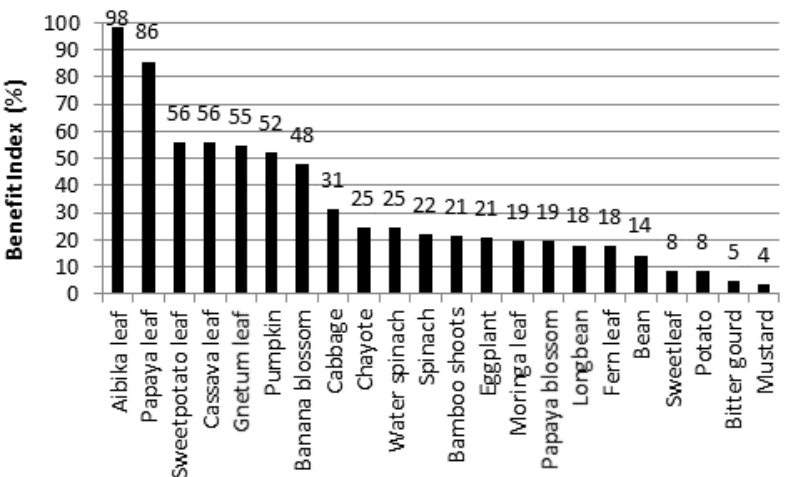

Figure 4. Benefit index of vegetable crops consumed by the people of Sukumi, Yumboi, and Watitindauw villages, West Papua Province, Indonesia

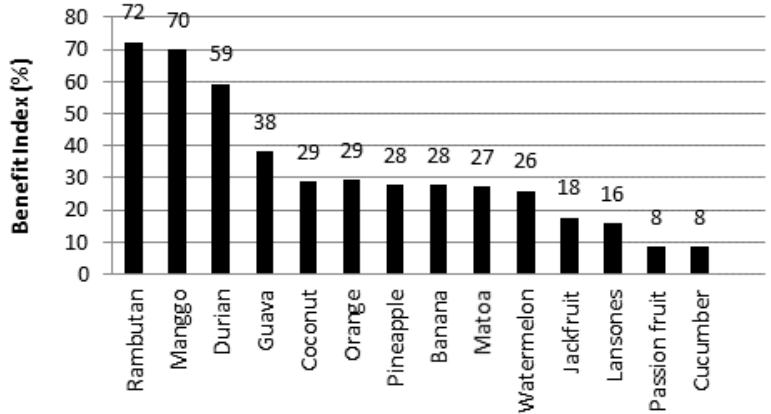

Figure 7. Benefit index of types of fruit crops
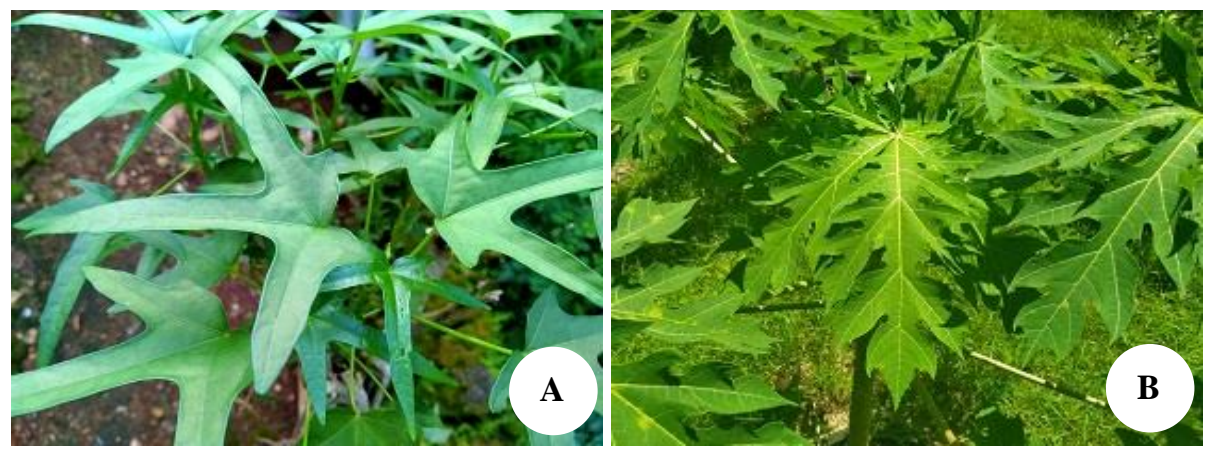

Figure 5. The highest benefit index of vegetable crops: (A) aibika or gedi leaf and (B) papaya leaf

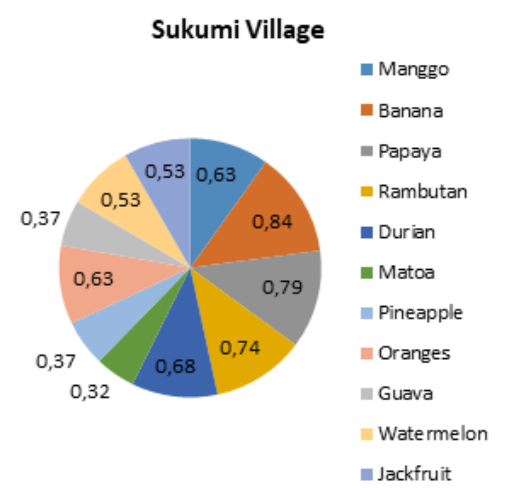

A

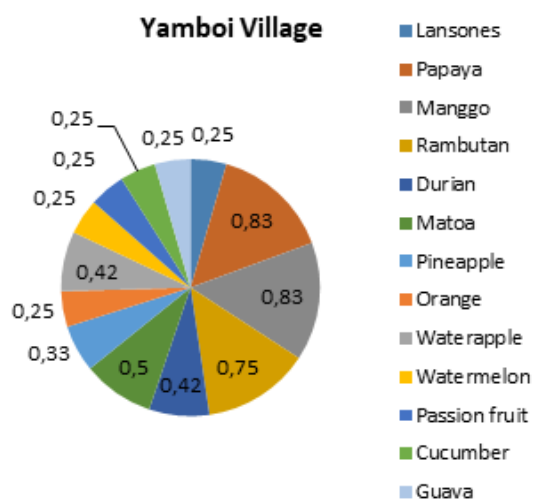

B

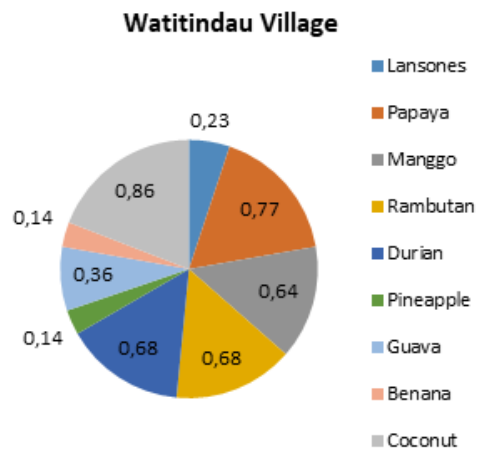

C

Figure 6. Types of fruits that are preferred by the people of West Papua Province, Indonesia: A. Sukumi, B. Yumboi, C. Watitindau villages
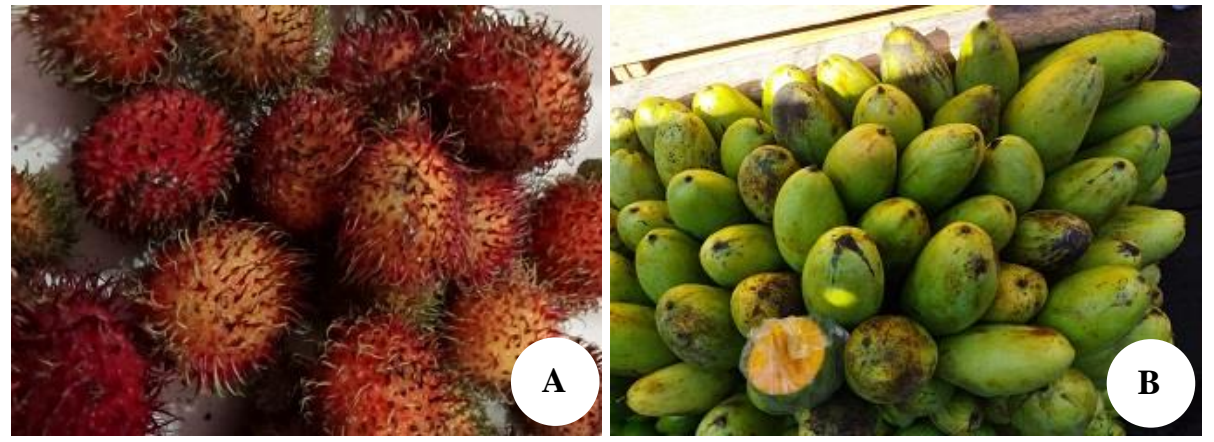

Figure 8. The highest benefit index of fruit crops: (A) rambutan and (B) mango 
Whilst in the three villages, papaya leaves were in second place, sweet potato leaves in third and cassava leaves in fourth (Figure 4). According to Lyons et al. (2015), a more traditional lifestyle, especially with respect to health, is needed to address the alarming rates of obesity, heart disease, and diabetes; and that leafy vegetables which are traditionally consumed by Pacific Island people should play an important role. Gedi, for example, has been shown to have anti-diabetes effects (Kim et al. 2018). van Rensburg et al. (2007) stated that the use of local leafy vegetables among people in remote rural areas is still common, but in urban areas particularly, there is evidence of decline.

In addition to the nutritious fruit, the papaya leaves are vegetables that had the second benefit index after gedi leaves (Figure 4). Papaya leaves are not only nutritious but also have therapeutic properties and have been used for therapeutic applications. Papaya leaves are commonly used in Papua to treat malaria disease or dengue fever. According to Singh et al. (2020), papaya leaf extract has strong medicinal properties such as antibacterial, antiviral, antitumor, hypoglycemic, and anti-inflammatory activities, as it contains active compounds such as alkaloids, glycosides, tannins, saponins, and flavonoids. This shows that the existence of the RIC program does not necessarily change the community's dependence on recently introduced types of vegetables such as mustard greens, beans, and so on. The reason is that the cultivation of local vegetable crops is uncomplicated and does not require intensive cultivation inputs and supervision compared to recently introduced vegetable crops.

\section{Benefit index of fruit crops}

Figure 6 shows the types of fruit most consumed by the people in Sukumi, Yamboi, and Watitindauw villages. Each region has an abundance of fruit plants that are relatively the same. The fruits that are widely consumed are bananas, papaya, guava, rambutan, and many more. Bananas were widely consumed by the people of the Sukumi Village. Banana is a plant that can easily adapt and has developed for a long time in the history of agricultural crop cultivation in Papua. Bananas are a group of horticultural plants (fruits), but in Papua, bananas are also consumed as food crops or as a source of carbohydrates. Unripe bananas are grilled and consumed.

Local well-adapted fruit plants in the three villages were mango, papaya, langsat, rambutan, durian, guava, and jackfruit. These fruits grow in the community's house yards and gardens. Relatively new, introduced fruit plants include pineapple, passion fruit, watermelon, and sweet orange.

Rambutan had the highest benefit index, followed by mango and durian (Figure 7). These three plants, apart from being consumed alone, also provide relatively large household incomes because their selling prices are higher than some other fruits. With global climate change, the time and frequency of harvesting the three crops tend to change. The harvest time of the previous decade was once a year, and now it could be twice per year. These results indicate that the inclusion of the RIC program does not affect people's preferences in the cultivation and consumption of newly introduced fruit crops.

To conclude, the Remote Indigenous Community Empowerment Program has influenced the preferences of the local staple food crops of people in Sukumi, Yamboi, and Watitidauw villages. People in these villages have slowly shifted to rice when the RIC program has been implemented and transport facilities or infrastructure has developed. However, people in these villages still also consume the local staple food, as rice is not always available. The shift from local staple food to rice may create a problem when they leave the local staple food and become dependent fully on rice. On the other hand, certain local fruits and vegetables still dominate in these villages compared to the introduced ones. Banana and root crops (sweet potato, taro, and cassava) had the highest benefit index (BI) as the local staple food, while the highest BI of vegetable crops was aibika (gedi) and papaya leaf (Figure 5). In addition as fruit crops, rambutan and mango had the highest BI (Figure 8).

\section{ACKNOWLEDGEMENTS}

The authors thank the communities of Domberi traditional territory, particularly the indigenous peoples, tribal chiefs, traditional figures, and leaders in Sakumi, Watitindau, and Yamboi villages who were involved in the interview and discussion, and for their helpfulness and kindheartedness during the data collection.

\section{REFERENCES}

Anggraeni T. 2020. A Comparative study of Indonesian estimated rice production and consumption. Jurnal Analisis Kebijakan dan Pelayanan Publik 6 (2): 101-112. DOI: 10.31947/jakpp.vi.9279. [Indonesian]

Arwam H, Supriantono A, Holle Y, Sawaki YW. 2021. Prohibition for a better life in the future local knowledge of Negeri Besar village South Sorong District. World J Adv Res Rev 10 (3): 77-84. DOI: 10.30574/wjarr.2021.10.3.0177.

Aswani S, Lemahieu A, Sauer WHH. 2018. Global trends of local ecological knowledge and future implications. Global trends of local ecological knowledge and future implications. PLoS ONE 13 (4): e0195440. DOI: 10.1371/journal. pone.019544.

Batoro J. 2015. Pengelolaan lingkungan: dengan pendekatan etnobiologietnobotani. Universitas Brawijaya Press, Malang, Indonesia. [Indonesian]

Bilali HE, Callenius C, Strassner C, Probst L. 2018. Food and nutrition security and sustainability transitions in food systems. Food Energy Secur 8 (2): e00154. DOI: 10.1002/fes3.154.

Cassino MF, Alves RP, Levis C, Watling J, Junqueira AB, Shock MP, Ferreira MJ, Andrade VLC, Furquim LP, Coelho SD, Tamanaha EK, Neves EG, Clement CR. 2018. Ethnobotany and ethnoecology applied to historical ecology. Methods and Techniques in Ethnobiology and Ethnoecology. Springer Protocols Handbooks. Humana Press, New York, NY. DOI: 10.1007/978-1-4939-89195_13.

Carvalho and Moreira F. 2011. Importance of local knowledge in plant resources management and conservation in two protected areas from Trás-os-Montes, Portugal. J Ethnobiol Ethnomed 7 (36): 1-13. DOI: 10.1186/1746-4269-7-36

Chen P, Wan Y, Wang C, Zhao Q, Wei Q, Tu Y, Yin X. 2012. Mechanisms and effects of Abelmoschus manihot preparations in treating chronic kidney disease. China J Chin Mater Med 37 (15): 2252-2256. 
Coelho FC, Coelho EM, Egerer M. 2018. Local food: benefits and failings due to modern agriculture. Scienta Agricola 75 (1): 84-94. DOI: 10.1590/1678-992X-2015-0439.

Domingo A, Chales KA, Jacobs M, Brooker D, Hanning RM. 2021 Indigenous community perspectives of food security, sustainable food systems and strategies to enhance access to local and traditional healthy food for partnering Williams Treaties First Nations (Ontario, Canada). Intl J Environ Res Public Health 18 (9): 4404. DOI: 10.3390/ijerph18094404.

Hatu RA. 2020. The remote indigenous community empowerment based on local wisdom (Case study Limbula, Wanggarasi, Pohuwato, Gorontalo, Indonesia). J Seybold Rep 15 (9): 1432-1444.

Helida A, Zuhud EAM, Hardjanto, Purwanto Y, Hikmat A. 2016. Retention and change of ethnobotanical knowledge at Kerinci community in Kerinci Seblat National Park. Buletin Kebun Raya 19 (2): 105-116. DOI: 10.14203/bkr.v19i2.165. [Indonesian]

Islam S. 2006. Sweet potato (Ipomoea batatas L.) Leaf: Its potential effect on human health and nutrition. J Food Sci 71 (2): R13-R121. DOI: 10.1111/j.1365-2621.2006.tb08912.x

Iswandi RM, Basri LOA, Adijaya S, Alwi LO and Arif K. 2015. Empowerment of remote indigenous community. Am-Eur J Sustain Agric 9 (7): 1-7.

Kim H, Dusabimana T, Kim S, Je J, Jeong K, Kang M, Cho K, Kim H, Park S. 2018. Supplementation of Abelmoschus manihot (Malvaceae) on type 2 diabetic nephropathy and hepatic steatosis by activating autophagy in mice. Nutrients 10: 1703. DOI: 10.3390/nu10111703.

Leret CR, Zambrana PN, Balslev H, Maci'a MJ. 2014. Ethnobotanical knowledge is vastly under-documented in Northwestern South America. PLoS ONE 9 (1): e85794. DOI: 10.1371/journal.pone.0085794.

Lyons G, Goebel RG, Tikai P, Stanley KJ, Taylor M. 2015. Promoting nutritious leafy vegetables in the Pacific and northern Australia. Acta Hortic 1102: 253-260. DOI: 10.17660/ActaHortic.2015.1102.31.

Lyons G, Dean G, Tongaiaba R, Halavatau S, Nakabuta K, Lonalona M, Susumu G. 2020. Macro and micronutrients from traditional food plants could improve nutrition and reduce non-communicable diseases of Islanders on atolls in the South Pacific. Plants 9: 942-956. DOI: $10.3390 /$ plants9080942

Mohanraj R, Sivasankar S. 2014. Sweet potato (Ipomoea batatas [L.] Lam - A valuable medicinal food: A Review. J Med Food 17 (7): 733 741. DOI: $10.1089 / \mathrm{jmf} .2013 .2818$.
Miles MB, Hubermen AM. 1994. Qualitative Data Analysis. $2^{\text {nd }}$ ed. Sage Publications. International Educational and Professional Publisher, London.

Ramandey L. 2017. Dampak sosial program pembagian beras miskin (RASKIN) di Kampung Amar Distrik Amar Kabupaten Mimika, Papua. Universitas Cenderawasih, Jayapura, Indonesia. [Indonesian]

Saraswati P, Djuuna AF, Asyerem F, Yaku A. 2006. Morphological diversity and the cultivation practice of Abelmoschus manihot in West Papua, Indonesia. Biodiversitas 17 (2): 894-999. DOI: 10.13057/biodiv/d170267.

Simbiak M. 2016. Tinjauan etnoekologi dan beberapa penelitian di Indonesia. Novae Guinea Jurnal Biologi 7 (1): 27-42. DOI: 10.15578/jppi.7.4.2001.1-8. [Indonesian]

Singh SP, Kumar S, Mathan SV, Tomar MS, Singh RK, Verma PK, Kumar A, Kumar S, Singh RP, Acharya A. 2020. Therapeutic application of Carica papaya leaf extract in the management of human diseases. DARU J Pharm Sci 28: 735-744. DOI: 10.1007/s40199-020-00348-7.

Statistical Central Bureau of West Papua (BPS). 2016. Papua Barat Dalam Angka. Badan Pusat Statistik Papua Barat. [Indonesian]

Statistical Central Bureau of West Papua (BPS). 2020. Papua Barat Dalam Angka. Badan Pusat Statistik Papua Barat. [Indonesian]

Suradi, Nulhaqim SA, Mulyana N, Suharto E. 2019. Indigenous peoples, poverty and the role of social workers. Asian Soc Work J (ASWJ) 4 (1): 11-19. DOI: $10.47405 /$ aswj.v4i1.73.

Tjokrokusumo D. 2018. Potency of sago (Metroxylon spp.) crops for food diversity. Biodivers Intl J 2 (3): 239-240. DOI: 10.15406/bij.2018.02.00066.

Todarwal A, Jain P, Bari S. 2011. Abelmoschus manihot Linn: Ethnobotany, phytochemistry and pharmacology. Asian J Tradit Med 6 (1): 1-7.

Tuia VS, Kambuou R, Paofa J, Malapa R, Robert N, Hadosaia C, Navukiboro C, Fink A, Waqainabete LM, Sukal A, Shandil AS. 2015. Sustainable conservation and utilisation of bele (Abelmoschus manihot), a pacific indigenous vegetable. XXIX International Horticultural Congress on Horticulture: Sustaining Lives, Livelihoods and Landscapes (IHC2014). International Symposium on Promoting the Future of Indigenous Vegetables Worldwide. DOI: 10.17660/ActaHortic.2015.1102.6.

van Rensburg WSJ, van Averbeke W, Slabbert R, Faber M, van Jaarsveld P, van Heerden I, Wenhold F, Oelofse A. 2007. African leafy vegetables in South Africa. Afr J 3 (33): 317-362. DOI: 10.4314/wsa.v33i3.180589. 